\title{
A questionnaire study of injections prescribed and dispensed for patients diagnosed with $\mathrm{mild} /$ moderate community- acquired pneumonia in Mongolia
}

Gereltuya Dorj, Delia Hendrie, Richard W Parsons, Bruce Sunderland

Purpose: The study aimed to determine the extent of and factors influencing the prescribing of injections for the treatment of mild/moderate community acquired pneumonia (CAP) in Mongolia. Methods: Questionnaires were developed and administered to medication providers (34 Pharmacists, 27 pharmacy technicians) and prescribers (22 general doctors and 49 medical specialists) working in Mongolia. Results: Cefalosporins were prescribed for patients with mild pneumonia and doctors tended to prescribe injectable cefalosporins (cefazolin) rather than oral dosage forms. This was supported by the questionnaire study with pharmacists and pharmacy technicians. Additionally, 23 pharmacists and pharmacy technicians indicated that OTC injectable cefalosporins (37.7\%) and injectable aminopenicillins (33,9\%) were frequently sold by pharmacies for the treatment of mild/ moderate CAP. Doctors and particularly pharmacists in the questionnaire studies indicated choosing an injection was to avoid non-compliance problems. Conclusion: High levels of injectable prescribing of antibiotics were found in nonhospitalized patients with CAP in Mongolia. This prevalence level indicated that inappropriate injection prescribing is a public health hazard for Mongolia and requires consideration by the appropriate authorities. 


\section{Cover page}

2 Title: A questionnaire study of injections prescribed and dispensed for patients diagnosed with

3 mild/moderate community-acquired pneumonia in Mongolia

4 Authors: Dr.Gereltuya Dorj (PhD)- Lecturer, School of Pharmacy and Biomedicine, Mongolian National

5 University of Medical Sciences, Ulaanbaatar, Mongolia - Corresponding author

6 Tel: +97695018988 Fax: +97611 326947, Email: gereltuya@gmail.com

7 Ms Delia Hendrie -Senior Research Fellow, School of Public Health Curtin University GPO Box U1987

8 Perth, Western Australia 6845 Australia

9 Tel: +618 9266 9068, Fax: +6189266 2958, Email: D.V.Hendrie@curtin.edu.au

10 Dr. Richard Parsons (PhD)- Senior Lecturer, School of Pharmacy, Bentley, Curtin University, GPO Box

11 U1987, Western Australia 6845,

12 Tel: +6189266 3691, Email: R.Parsons@curtin.edu.au

13 Professor Bruce Sunderland (PhD), School of Pharmacy, Bentley, Curtin University, GPO Box U1987,

14 Western Australia 6845,

15 Tel: +6189266 7377, Fax: +6189266 2769, Email: B.Sunderland@,curtin.edu.au

16 Abstract

17 Purpose: The study aimed to determine the extent of and factors influencing the prescribing of injections for the treatment of patients diagnosed with mild/moderate community acquired pneumonia (CAP) in Mongolia. 
20 Methods: Questionnaires were developed and administered to medication providers (34

21 Pharmacists, 27 pharmacy technicians) and prescribers (22 general doctors and 49 medical

22 specialists) working in Mongolia.

23 Results: Cefalosporins were prescribed for patients with mild pneumonia and doctors tended to 24 prescribe injectable cefalosporins (cefazolin) rather than oral dosage forms. This was supported 25 by the questionnaire study with pharmacists and pharmacy technicians. Additionally, 23 26 pharmacists and pharmacy technicians indicated that OTC injectable cefalosporins (37.7\%) and 27 injectable aminopenicillins $(33,9 \%)$ were frequently sold by pharmacies for the treatment of $28 \mathrm{mild} /$ moderate CAP. Doctors to some extent and particularly pharmacists in the questionnaire 29 studies indicated choosing an injection was to avoid non-compliance problems.

30 Conclusion: High levels of injectable prescribing of antibiotics were found in non-hospitalized

31 patients with CAP in Mongolia. These findings should inform the development of strategies to

32 decrease inappropriate use of injections for the treatment of mild/ moderate CAP in Mongolia. 


\section{Introduction}

34 Medicines are commonly administered by injection in healthcare settings for the prevention,

35 diagnosis, and treatment of various illnesses. Unsafe injection practices including the re-use of

36 equipment without sterilization has been associated with a wide variety of procedures and

37 settings and puts patients and healthcare providers at risk of infectious and non-infectious

38 adverse events. ${ }^{1}$

The global burden of disease project (World Health Organization [WHO]) conducted a literature review and found that the annual number of single injections administered per person ranged from 1.7 to 11.3 per year. ${ }^{2}$ A systematic review of studies from 13 developing countries regarding injection use and safety reported that for eight of those countries, $25-96 \%$ of outpatient visits resulted in at least one injection, and for five countries a majority of the administered injections was unnecessary. ${ }^{3}$ An assessment of injection practices in Mongolia showed a high injection frequency rate; reporting an average of 13 injections per person per year amongst a small sample of 65 participants and the most common reason for an injection was community-

47 acquired pneumonia (CAP). ${ }^{4}$

CAP accounts for $95 \%$ of all pneumonia cases in the world among children aged less than five

49 years of age. ${ }^{5}$ In a prospective study in five countries of factors of CAP caused by bacteraemic pneumococcal disease, death rates ranged from $6 \%$ in Canada to $20 \%$ in the USA, $13 \%$ in the

51 UK and 8\% in Sweden. ${ }^{6}$ The mortality rate from CAP for children aged less than five was $34.4 \%$ in 2011 in Mongolia and was the second most common reason for all hospitalizations in 2011 amongst children $(46 \%) .{ }^{7}$ The general consensus is that pneumonia should be treated with antibiotics and for those with mild/moderate CAP oral administrationis appropriate. ${ }^{8,9}$ 
55 The Mongolian standard treatment guidelines (STGs) for adult and paediatric patients are

56 available and widely accessible in the Mongolian language. For adult patients, the STGs

57 recommend oral amoxicillin (ampicillin) 500mg every 6 hours or erythromycin 500mg every 6

58 hours. ${ }^{10}$ The treatment standard for paediatric pneumonia is classified into infants and children

59 aged up to five years old. The STGs for infant patients diagnosed with mild/ moderate CAP

60 recommends benzylpenicillin, aminoglycoside (gentamicin) injection. Treatment of children

61 aged up to five years old should include semi-synthetic penicillin $(50 \mathrm{mg} / \mathrm{kg} / 4$ times $)$ plus

62 gentamicin $7.5 \mathrm{mg} / \mathrm{kg} /$ once)-injection and other options include cephalosporin generations II-III.

63 In addition, any of the following could be prescribed for children aged up to five years can be

64 prescribed: salbutamol, euphyllin, epinephrine, prednisolone, dexamethasone, vitamin C, A or E,

65 if considered to be necessary.

66 The reasons for prescribing parenteral medications in developing countries include socio-

67 cultural, economic and structural factors. The belief in injections as a strong tool for restoring

68 and maintaining health is mutually supported by health professionals and community members in

69 many developing countries. ${ }^{11}$ Previous studies have indicated poor knowledge of the associated

70 risks and burden of unsafe and unnecessary injection practices and easy access to parenteral

71 medication contributes to the popularity of injections in developing countries. ${ }^{12-14}$

\section{Objective}

73 The study aimed to determine the extent of, and factors influencing the prescribing of injections

74 for the treatment of patients diagnosed with mild/ moderate CAP in Mongolia 
75

76

77

78

79

80

81

82

83

84

85

86

87

\section{Materials and methods}

Two questionnaires were developed using a WHO/SIGN guide. ${ }^{15}, 16$ This guide included information relevant to investigation of injection practices, their determinants and their consequences. In addition, face validation of both questionnaires was performed with pharmacy academics and practitioners from Australia and Mongolia, to ensure the validity of questions exploring doctors' and pharmacist's practises of prescribing, dispensing and supplying injections for the treatment of CAP in Mongolia. Content validation was carried out with three family group practitioners and two specialists practising in a conveniently selected large central hospital (for the doctor questionnaire). The one for pharmacists and pharmacy technicians was tested with two pharmacists and two pharmacy technicians working in randomly selected pharmacies (representing the pharmacists). The purpose of the piloting phase was to ensure that the questions were clear, and achieved the objectives of the study. In addition it was important that the instrument could be completed in a reasonable amount of time. Following their feedback and discussion with local professionals, the wording and order of some the questions were modified. The responses collected during the pilot studies were not used for further analyses. Respondents could choose more than one option in questions regarding the prescribing and dispensing practice of antibiotics and non-antibiotics for the treatment of mild/moderate CAP.

\section{Selection of study sites}

As recommended in the WHO guide, ${ }^{16}$ three large urban districts (based on population size), two sub-urban districts (Nalaikh, Baganuur) located in Ulaanbaatar known to be representative of all socioeconomic groups in Mongolia were selected. There are three public central hospitals, eight specialized centres, nine district hospitals, six private hospitals and 126 Family Group Practices (FGPs) located in Ulaanbaatar. ${ }^{17}$ Selection of health facilities was done purposively based on 
98 their location and accessibility. For the study, three public central hospitals in large districts,

99 three district hospitals in urban and two district hospitals in sub-urban districts, three private

100 hospitals in sub-urban districts and 20 FGPs located in both large and small (sub-urban) districts

101 were purposively selected.

102 A purposive sample of forty community pharmacies was selected from the five districts to 103 represent a range of pharmacies based on their size, accessibility and distance from clinics, 104 following discussions with local professionals, and ensuring that no particular type of pharmacy 105 was excluded. These included 12 of the 22 pharmacies consenting to a previous study and a 106 further 28 pharmacies were approached. ${ }^{18}$ In respect to their location, 25 community pharmacies 107 were located in three large districts and15were in two sub-urban districts.

108 Doctors working in the above-mentioned health facilities were randomly selected from the list of 109 actively working employees, provided by human resource offices in the selected sites.

110 Pharmacists and pharmacy technicians were conveniently selected from the pharmacies.

\section{Administration of the questionnaires}

112 After obtaining verbal consent, a self-administered questionnaire was distributed by hand to

113 eligible participants (pharmacist and/or pharmacy technician, doctor and/or specialist) working

114 in community pharmacies or hospitals in urban and sub-urban districts of Ulaanbaatar, Mongolia.

115 In order to improve the response rate, the survey was issued in the early mornings or when the 116 participants were able to focus on the survey. No more than two respondents were selected from

117 the same pharmacy or clinic and where there were two, they were a pharmacist and a pharmacy 118 technician or a doctor and a specialist. Respondents completed the questionnaire independently, 
119 if there were more than one respondent at the same setting. The questionnaires were collected

120 from pharmacies and clinics by the researcher.

\section{Data analysis}

122 Standard descriptive statistics were used to summarize demographic data and responses to the 123 questionnaires. Questions regarding the frequency of dispensed/prescribed medicines for the 124 treatment of CAP were answered using a five-point Likert scale ranging from never to always. 125 For some analyses, the responses were condensed into three categories (never/rarely, sometimes, 126 and often/always). Responses using Likert scales that ranged from strongly agree to strongly 127 disagree were similarly formed into two groups, strongly agree/agree, and disagree/strongly 128 disagree. For other analyses, the Likert scale responses were coded from one to five, so that 129 mean scores and standard deviations could be calculated and used to compare differences 130 between groups.

131 The mean values of responses measured on a Likert scale may be assumed to be normally 132 distributed, as the number of respondents was large $(>30)$ in each group, pharmacy and 133 pharmacy technicians-(61), doctors-(71) (Central Limit Theorem). ${ }^{19}$

134 Comparisons between groups based on route of administration (injection versus oral/other), 135 setting (private versus public) and professional level (pharmacist versus pharmacy technician)

136 were performed using the Chi-square test, logistic regression or Kruskal-Wallis test with a 137 pairwise comparison as appropriate. A $\mathrm{p}$ value of $<0.05$ was taken as indicating a statistically 138 significant difference.

\section{Ethical considerations and confidentiality}


140 The study protocol was approved by the Human Research Ethics Committee, Curtin University,

141 Western Australia (PH-11-2010). The questionnaire study was completed during January until

142 May, 2010.

143 Data accessibility and sharing

144 Extra data are available by emailing the corresponding author (GD).

145 Results

146 Questionnaires were distributed to 45 pharmacists and 35 pharmacy technicians $(n=80)$. An

147 overall response of $61(76.3 \%)$ completed survey forms were returned from the 'pharmacy

148 group'. Pharmacists (11) and pharmacy technicians (8) who did not consent were working in

149 pharmacies located in the large districts. The refusal was due to busy workload and

150 unwillingness to participate.

151 A majority of respondents was female (77.0\%), and most were aged between 31 and 50 years. A

152 little over half were pharmacists (55.7\%), and most respondents had been working for one to five

153 years (65.6\%).The study included one pharmacist, and/or pharmacy technician from each

154 pharmacy and accordingly they were visited in their working area. Where the two were at the

155 same pharmacy, they completed the questionnaire independently.

156 In addition, questionnaires were distributed to 80doctors of whom35 were general practitioners

157 (GPs) and 45were medical specialists. The response rate was $88.8 \%(71 / 80)$ and $83.1 \%$ were

158 female doctors, which is comparable to the gender distribution of all doctors in Mongolia

159 (79.1\%). ${ }^{7}$ Most respondents were working in public hospitals and about $70 \%$ were specialists. A

160 majority was over 30 years of age (63.4\%) with a monthly income of over 300.000 MNT 
161 (Mongolian National Tugrug, currency, 100 USD is equivalent to $130,000 \mathrm{MNT}$ at the time of 162 study)(Table 1).

163 Pharmacists and pharmacy technicians reported that injections were prescribed and dispensed for 164 the treatment of mild/moderate CAP. Commonly prescribed antibiotics that were dispensed were 165 ampicillin injections (52.5\%), injectable cefalosporins (75.4\%) and injectable quinolones 166 (55.7\%). These were more frequently dispensed than the oral forms. Oral macrolides $(50.8 \%)$ 167 were dispensed more frequently than an injection (Table 2).

According to the current regulations, only qualified medical doctors can prescribe prescription medicines approved by the order of the Minister of Health to patients. ${ }^{20}$ However, the provision of over the counter (OTC) medicines, including injections occurs in Mongolian pharmacies. ${ }^{21,22}$ Pharmacists and pharmacy technicians were asked to indicate their practice of providing OTC antibiotics for the treatment of CAP. Most reported they never or rarely provided OTC medicines (65.0\%); on the other hand 13 pharmacists and pharmacy technicians $(21.7 \%)$ provided OTC antibiotics sometimes. However, when presented with questions related to medicines that were provided OTC, the respondents indicated a higher frequency of commonly provided OTC antibiotics, for example: injectable penicillins with extended spectrum (e.g. ampicillin)(36.1\%). Additionally, respondents indicated that OTC injectable (37.7\%) and oral cefalosporins (31.1\%) were frequently provided. In contrast, injectable macrolides were less frequently provided $(10.9 \%)($ Table 2$)$.

Other medicines dispensed with a prescription for the treatment of CAP included mucolytics $(50.8 \%)$, oral vitamins $(38.7 \%)$ and oral antihistamines $(21 \%)$. Additionally, injectable corticosteroids (29.5\%) and injectable xanthins $(22.0 \%)$ were frequently dispensed non- 
183 antibiotics (Table 3). There was also some provision of oral or injectable non-antibiotic OTC

184 medicines from pharmacies with regards to corticosteroids (about 10\%) and pyrazolones

185 (13\%).Again, similar to the medicines dispensed with a prescription, the most common OTC

186 medicines provided for treatment of CAP were oral vitamins and oral xanthins(Table 3).

187 In order to gain an understanding the underlying reasons for prescribing and providing OTC 188 injections, respondents were asked to indicate the extent to which they agreed with issues that 189 influenced their provision practice of OTC medicines (Table 4).

Most respondents commonly reported that injections were provided if patients had severe CAP 191 (pharmacists and pharmacy technicians [79.3\%,] doctors [47.9\%]). A majority of pharmacists and pharmacy technicians strongly agreed that injections were provided OTC to achieve better patient compliance with treatment $(68.4 \%)$, however this reason was supported by only eleven doctors $(15 \%)$.Male doctors tended to agree more than females with injections improving patient compliance with a treatment regimen $[\mathrm{p}=0.011$, (male $\mathrm{M}=3.0, \mathrm{STD}=1.17, \mathrm{f}: \mathrm{M}=2.0, \mathrm{STD}=0.9)]$. and $44 \%$ of doctors specified that the clinical effect of injections was better than oral medicines. No significant relationship was observed between pharmacists and pharmacy technicians $[p=0.59]$. Additionally, the proportion of pharmacists supporting the idea that medication outcomes from injections were better than tablets or capsules tended to be greater $(62.5 \%)$ than

201 pharmacy technicians (53.8\%), yet, it was not statistically significant: [p=0.51].Most 202 pharmacists, including pharmacy technicians (59\%) and some doctors (41\%) stated that the 203 pharmaceutical quality of injections was better than oral medicines. 
204 About $70 \%$ of pharmacists including pharmacy technicians did not support the view that adverse

205 effects occurred more with oral medications than with therapeutic injections. Similarly, only

$20614 \%$ of doctors agreed that the prevalence of side effects was lower with injections than with oral

207 medicines. In addition,21 pharmacists and pharmacy technicians (36.2\%) strongly agreed/agreed

208 that the cost of treatment with injections was higher than with oral medicines. However, only 15

209 doctors (21\%) supported this.

210 A similar number of doctors (29\%) and pharmacists plus pharmacy technicians $(23.9 \%)$

211 supported the statement that patients preferred oral medicines over injections (Table 4).

\section{Discussion}

213 This study was undertaken to quantitate the levels injection prescribing by doctors and provision

214 OTC by community pharmacies from their perspectives, for the treatment of mild/moderate CAP

215 in Mongolia. Importantly it has identified some factors influencing the prescribing of injections

216 which could lead to interventions to improve the underlying quality of prescribing and reduce

217 that public health hazards associated with the administration of injections.

218 Pharmacists and pharmacy technicians indicated that only $21.7 \%$ provided OTC antibiotics

219 sometimes. However, the frequency of OTC injectable antibiotics provided was reported as

220 higher elsewhere in the same questionnaire, possibly better indicating real practice when

221 compared with previous findings. ${ }^{23}$ Oral and injectable aminopenicillins (ampicillin or

222 amoxicillin) were commonly prescribed ${ }^{18}$ and this was confirmed by the questionnaire study

223 with pharmacists, including pharmacy technicians and doctors. This practice was in compliance

224 with the guidelines. ${ }^{24}$ However, the guidelines allow for only oral aminopenicillins for adult and

225 pediatric patients yet27.9\% of prescribing were injections. Pharmacists and pharmacy 
226 technicians indicated a higher likelihood of supplying OTC oral or injectable aminopenicillins

227 (37.7\% versus 33.9\%). Cefalosporins were prescribed for patients with mild pneumonia and

228 doctors tended to prescribe injectable cefalosporins (cefazolin) rather than oral, and this was

229 supported by the questionnaire study with pharmacists and pharmacy technicians. OTC sales of

230 cefazolin were also reported in the questionnaire study, but the pharmacists and pharmacy

231 technicians did not indicate any preference for either of the dosage forms.

232 The range of non-antibiotic medicines prescribed for patients with mild/moderate CAP included

233 vitamins, mucolytics, corticosteroids and antihistamines. ${ }^{18}$ The prescription results however

234 showed that only four injectable vitamins were prescribed. This is in contrast to the questionnaire

235 studies where doctors indicated a higher frequency of prescribed injectable vitamins $(25.8 \%)$

236 often/always for patients with mild CAP. The practice of selling by pharmacies of injectable

237 vitamins OTC was also found to be at a similar level (21\%). The practice of providing vitamin

238 injections OTC is not consistent with current STGs. Detailed results from a previously reported

239 prescription analysis ${ }^{18}$ and these questionnaire studies showed that vitamin $\mathrm{C}$ was frequently

240 prescribed and dispensed for the treatment of mild/moderate CAP. This could reflect a low fresh

241 food intake containing necessary vitamins, leading to micronutrient deficiencies in Mongolia. ${ }^{25}$,

$242{ }^{26}$ A Cochrane review of five trials suggested vitamin $\mathrm{C}$ was beneficial in both prevention and

243 treatment of pneumonia. However, caution must be exercised with generalizations made from

244 trials owing to the conditions in which the trials were conducted. But for patients who have low

245 plasma vitamin C levels, intake of vitamin C would be beneficial. ${ }^{27}$

246 The questionnaire studies with doctors and pharmacists including pharmacy technicians

247 indicated that they chose an injection if the patient was severely ill. This perspective is consistent

248 with guidelines and several findings from other countries. ${ }^{28-30}$ Likewise, considering the period 
249 of study (cold winter) and risk of deterioration of the patient, this practice may reflect clinical

250 concern. However, choosing an injection for adult patients with mild/moderate CAP is non251 compliant with current STGs. ${ }^{31,32}$

252 Financial considerations are another important reason why injections were preferred by 253 prescribers and providers. In this study most respondents acknowledged that the cost of treatment 254 with injections was higher than with oral medicines. Economic incentives from prescribing an 255 injection were reported in a previous study where $19 \%$ of high rate injection prescribers admitted having economic incentives for prescribing injections in Iran. ${ }^{33}$ The large number of doctors on a population basis practising in Mongolia maybe a potential factor for doctors to seek additional income sources.

Additionally, one of the factors that contributed to the inappropriate use of injections in

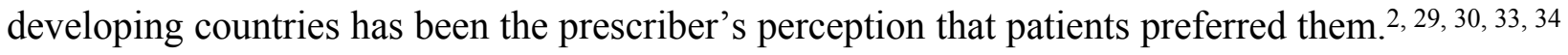
In this study, approximately $24 \%$ of doctors and $29 \%$ of pharmacists, plus pharmacy technicians strongly supported the notion that patients often/always preferred oral medications. This is contrasted with findings that only $16 \%$ of community members always/often expected injections to be prescribed. ${ }^{35} \mathrm{~A}$ previous research study that investigated maternal perception of mild pneumonia in an outpatient clinic found that $40 \%$ of mothers stated doctors should give their child at least one injection. However, the generalization of that report to a larger population might be questionable, due to a small number and poor understanding of the participants $(n=50) .{ }^{36}$ Other literature has confirmed that injections were often not preferred by patients, when they were advised about the clinical efficacy and potential risks associated with unsafe injection practices. ${ }^{34}$ Health workers in developing countries believed that patient's compliance was better with injections than with oral medication 37,38 and similarly, some doctors and 
272 particularly pharmacists in this study have indicated choosing an injection was to avoid non273 compliance problems.

\section{Limitations}

275 The reliability of the study results involved a triangulation method, matching the prescription 276 data from an earlier report with questionnaire responses from doctors, pharmacists and pharmacy 277 technicians. ${ }^{18}$ Despite the strengths of this study, some methodological aspects must be 278 considered when interpreting results. Firstly, the selection of pharmacists and pharmacy 279 technicians was based on a purposive selection of 40 community pharmacies. Also, the relatively 280 small number of samples of health settings (eleven hospitals and 20 FGPs located in Ulaanbaatar 281 city) may lead to selection bias and imprecise estimates. However, the high response rate of respondents in the questionnaire studies [pharmacists and pharmacy technicians $(76 \%)$, doctors$(89 \%)]$ was likely to avoid significant responder bias. In addition, the doctors were recruited randomly from the list provided by the human resource department of each hospital. This study recruited more specialists than general doctors, suggesting that the results may be more generalizable to them. However, the study included twenty-two general doctors, also providing information about their treatment of mild/moderate CAP patients.

In addition, the issue of compliance was only addressed in terms of whether it was an overall factor influencing the prescribing of injections over oral preparations which is the only dosage

290 form recommended for adults. Compliance is a complex issue for children as an injectable 291 product (gentamicin) is included in the STGs for children. From a compliance perspective for 292 children there is a range of factors influencing compliance dependent on the child's age and parental involvement and whether it is compliant with the daily dosing schedule or the duration

294 of the antibiotic or both. Hence this was too complex an issue to address fully in this study. 


\section{Conclusion}

296 Non-compliancewithSTGs in respect to prescribing injections for mild/ moderate CAP was

297 evident in Mongolia. In addition, the high prevalence of the prescribingof non-antibiotic

298 injections was inappropriate for mild/ moderate CAP. The supply of antibiotic injectionsOTC

299 from pharmacies although currently indicating a similar range of selections being made to those

300 prescribed by physicians should be ceased unless this would markedly reduce access to treatment

301 for poorer patients. Additional measures need to be put in place with the aim of reducing the high

302 level of inappropriate injections prescribed in Mongolia. It is notable that the current standard

303 treatment guidelines are followed by less than $40 \%$ of prescribers in Mongolia.

\section{Acknowledgements}

305 The authors are grateful to Ministry of Health, Division of Pharmaceuticals and Medical

306 Devices, staff at School of Pharmacy, Health Sciences University of Mongolia and for all

307 participants help to implement this study in Mongolia and for providing their helpful comments.

\section{Conflict of interests}

309 None declared. 
312 1. World Health Organization, The SIGN alliance. Injection Safety. WHO; [updated 313 2001; cited 7/9]. Available from: 314 http://www.who.int/injection safety/about/en/InjectionSafetyFirstDoNoHarm.pdf.

315 2. Yvan J F Hutin, Anja M Hauri, Gregory L Armstrong. Use of injections in 316 healthcare settings worldwide, 2000: literature review and regional estimates. BMJ. 3172003 ; 327(7423):1075. DOI:10.1136/bmj.327.7423.1075.

318 3. Simonsen L, Kane A, Lloyd J, Zaffran M, Kane M. Unsafe injections in the 319 developing world and transmission of bloodborne pathogens: A review. Bull World 320 Health Organ. 1999 [cited 15/05/2013]; 77(10):789-800. Available from: 321 http://www.who.int/bulletin/archives/77\%2810\%29789.pdf.

322 4. Logez Sophie, Soyolgerel Gochoo, Fields Rebecca, Luby Steve, Hutin Yvan. Rapid 323 assessment of injection practices in Mongolia. American Journal of Infection Control. 324 2004; 32(1):31-37. DOI:10.1016/j.ajic.2003.06.006.

325 5. Wardlaw TM, Johansson EW, Hodge MJ. Pneumonia: the forgotten killer of 326 children. United Nations Publications; 2006.

327 6. Kalin M, Örtqvist Å, Almela M, Aufwerber E, Dwyer R, Henriques B, Jorup C, 328 Julander I, Marrie TJ, Mufson MA. Prospective study of prognostic factors in 329 community-acquired bacteremic pneumococcal disease in 5 countries. Journal of 330 Infectious Diseases. 2000; 182(3):840-847. Available

331 7. Ariuntuya S, Narantuya Kh, Davaajargal S, Enkhjargal Ts, Unurtsetseg T. Health 332 Indicators of Mongolia 2011. Ulaanbaatar Mongolia Health Department of Mongolia

333 8. World Health Organization. Dept. of Child and Adolescent Health and 334 Development. Technical updates of the guidelines on the Integrated Management of 335 Childhood Illness (IMCI) : evidence and recommendations for further adaptations. 336 Geneva: World Health Organization; 2005; p. 38 p.

337 9. Antibiotic Expert Group. Therapeutic guidelines: antibiotic. , 2010. 338 Melbourne, Australia Therapeutic Guidelines Limited;

339 10. Batsereedene B, Naidansuren T, Oyunbileg Ts. Standard Guideline for Diagnosis 340 and Management of Common Diseases In: Pneumonia Ulaanbaatar Mongolia: Ministry of 341 Health, Mongolia; 2003 [cited 12/10]. Available from: 342 https://drive.google.com/file/d/OB7V1FtlR1y5VZGFxcnBPN1ViaWM/view?usp=sharing.

343 11. Berild Dag, Ringertz Signe Holta, Aabyholm Gunnar, Lelek Michaela, Fosse 344 Brita. Impact of an antibiotic policy on antibiotic use in a paediatric department. 345 Individual based follow-up shows that antibiotics were chosen according to diagnoses 346 and bacterial findings. International Journal of Antimicrobial Agents. 2002; 347 20(5):333-338. DOI:10.1016/s0924-8579(02)00203-0.

348 12. Birungi $\mathrm{H}$. Injections and self-help: risk and trust in Ugandan health care. 349 Soc Sci Med. 1998; 47(10):1455-1462. Available

350 13. Lakshman M, Nichter M. Contamination of medicine injection paraphernalia used 351 by registered medical practitioners in south India: an ethnographic study. Social 352 science \& medicine (1982). 2000 [cited 10/06/2013]; 51(1):11-28. Available from: http://www.sciencedirect.com/science/article/pii/S0277953699004268.

14. Reeler AV. Anthropological perspectives on injections : a review. Bull World Health Organ. 2000 [cited 17/06/2014]; 78(4):135-143. Available from: http://www.who.int/bulletin/pdf/2000/issue1/bu0130.pdf.

15. Hulscher ME, Richard PTM Grol, Jos WM van der Meer., . Antibiotic prescribing in hospitals: a social and behavioural scientific approach. The Lancet Infectious Diseases. $2010 ; 10(3): 8$. Available http://www.who.int/injection safety/about/en/InjectionSafetyFirstDoNoHarm.pdf. 
17. Information and Technology

Department of Ulaanbaatar. Health sector Ulaanbaatar, Mongolia 2013 [cited 13/05/2013]. Available from: http://www.ulaanbaatar.mn.

18. Dorj G, Hendrie D, Parsons R, Sunderland B. An evaluation of prescribing 366 practices for community-acquired pneumonia (CAP) in Mongolia. BMC Health Services 367 Research. 2013; 13(1):379. Available from: http://www.biomedcentral.com/1472$6963 / 13 / 379$.

369 19. Lumley T, Diehr P, Emerson S, Chen L. The Importance of the Normality Assumption in Large Public Health Data Sets. Annual Review of Public Health. 2002; 23(1):151-169. DOI:doi:10.1146/annurev.publhealth.23.100901.140546.

372 20. Ministry of Health Mongolia. Guideline for ambulatory care 2010

373 21. Margaret Cobey. Knowledge, attitudes and practices of therapeutic injection 374 use in Mongolia [M.P.H thesis]. U S A: University of Alaska

375

376

377

378

379

380

381

382

383

384

385

386

387

388

389

390

391

392

393

394

395

396

397

398

399

400

401

402

403

404

405

406

407

408

409

410

411

412

413

414

2011.

22. Tsolmongerel Tsivaajav, Evlegsuren Ser-Od, Bulganchimeg Baasai, Ganbat Byambaa, Shagdarsuren. 0. Health Systems in Transition Mongolia Health System Review Issue 2, 2013

23. Dorj Gereltuya, Sunderland Bruce, Hendrie Delia. Evaluation of prescribing practices for treatment of mild/moderate community-acquired pneumonia (CAP) in Mongolia [Ph.D thesis]. Perth, Western Australia: Curtin University; 2014.

24. Agvaandorj D, Galbadrakh L, Chinzorigt D, Chimgee G. Health care technology. Diagnosis and treatment of common diseases in children In: Pneumonia. Ulaanbaatar, Mongolia: Mongolian Centre for Standardization and Measurement; 2005 [cited 10/11]. Available from: http://www.estandard.gov.mn/file.php? sid=951.

25. Kachondham Y, Dhanamitta S, Oyunbileg M, Brown L. Child health and nutritional status in Ulaanbaatar, Mongolia: a preliminary assessment. Asia-Pacific Journal of Public Health. 1992; 6(4):226-232. Available

26. Lander RL, Tserennadmid Enkhjargal, Jamiyan Batjargal, Karl B. Bailey, Sarah Diouf, Timothy J. Green, C. Murray Skeaff, and Rosalind S. Gibson. Multiple micronutrient deficiencies persist during early childhood in Mongolia. Asia Pac J Clin Nutr. 2008; 17(3):429-40. Available

27. Hemilä H, Louhiala P. Vitamin C for preventing and treating pneumonia. Cochrane Database of Systematic Reviews. 2007; DOI:10.1002/14651858.CD005532.pub2.

28. Chowdhury AA, Tapash Roy, A. B. M. Faroque, Sitesh C. Bachar, Muhammad Asaduzzaman, Nishat Nasrin, Nahid Akter. A comprehensive situation assessment of injection practices in primary health care hospitals in Bangladesh. Bmc Public Health. 2011; 11 DOI:Artn 779

Doi 10.1186/1471-2458-11-779.

29. McIntosh K. Community-acquired pneumonia in Children. New England Journal of Medicine. 2002; 346(6):8. Available

30. Vong S, Joseph F. Perz, Srun Sok, Seiharath Som, Susan Goldstein, Yvan Hutin, and James Tulloch. Rapid assessment of injection practices in Cambodia, 2002. Bmc Public Health. 2005 [cited 16/1/2014]; 5(1):56. Available from: http://www.ncbi.nlm.nih.gov/pubmed/15929800.

31. Agvaandorj D, Galbadrakh L, Chinzorigt D, Chimgee G. Pneumonia. Health care technology. Diagnosis and treatment of common diseases in children Issue 25, 2008. Ulaanbaatar, Mongolia: Mongolian Centre for Standardization and Measurement;

32. Mongolian National Center for Standardization and Metrology. Standard for prescription (MNS 5376:2008), 2008. Ulaanbaatar, Mongolia

33. Ismaeilzadeh A, Nikfar S, Rahimi W. Physicians' Attitude Toward Injectable Medicines. Journal of Pharmacology and Toxicology. 2006 [cited 17/08/2013]; 1(1):3339. 
415 34. Hadiyono JEP, Suryawati S, Danu SS, Santoso B. Interactional group discussion: 416 results of a controlled trial using a behavioral intervention to reduce the use of 417 injections in public health facilities. Soc Sci Med. 1996 [cited 15/05/2014]; 418 42(8):1177-1183. Available from: 419 http://www.sciencedirect.com/science/article/pii/0277953695003916\#.

420 35. Srinivasan Arjun. A survey of knowledge, attitudes, and beliefs of house staff 421 physicians from various specialties concerning antimicrobial use and resistance. Archives of Internal Medicine. 2004; 164(13):5. Available

36. Malik Kundi MZ, Anjum M, Mull DS, Dennis Mull J. Maternal perceptions of pneumonia and pneumonia signs in Pakistani children. Soc Sci Med. 1993; 37(5):649660. DOI: http://dx.doi.org/10.1016/0277-9536(93)90104-C.

37. Michelle Kermode. Unsafe injections in low-income country health settings: need for injection safety promotion to prevent the spread of blood-borne viruses. Health Promotion International. 2004; 19(1):95-103. DOI:DOI 10.1093/heapro/dah110.

38. Anneloes van $\mathrm{S}$, Anita $\mathrm{H}$. Injection practices in the developing world : a comparative review of field studies in Uganda and Indonesia. Geneva: World Health 


\section{Table legends}

434

435 Table 1 Demographic characteristics of respondents

\begin{tabular}{|c|c|c|c|c|}
\hline \multirow[t]{2}{*}{ Variable ${ }^{a}$} & \multirow{2}{*}{\multicolumn{2}{|c|}{ Category }} & $\begin{array}{l}\text { Pharmacists and pharmacy } \\
\text { technicians }(\mathrm{N}=61)\end{array}$ & $\begin{array}{l}\text { Doctors } \\
(\mathrm{N}=71)\end{array}$ \\
\hline & & & $\mathrm{n}(\%)$ & n (\%) \\
\hline Age (years) & $\begin{array}{l}20-30 \\
31-50 \\
\geq 51\end{array}$ & & $\begin{array}{l}22(36.1) \\
23(37.7) \\
16(26.2)\end{array}$ & $\begin{array}{l}26(36.6) \\
45(63.4)^{c}\end{array}$ \\
\hline Gender & \multicolumn{2}{|l|}{$\begin{array}{l}\text { Male } \\
\text { Female }\end{array}$} & $\begin{array}{l}14(23.0) \\
47(77.0)\end{array}$ & $\begin{array}{l}12(16.9) \\
59(83.1)\end{array}$ \\
\hline Practice setting & $\begin{array}{l}\text { Owner } \\
\text { Employee }\end{array}$ & $\begin{array}{l}\text { Public hospital } \\
\text { Private setting } \\
\text { (including FGPs } \\
\text { and others) }\end{array}$ & $\begin{array}{l}12(19.7) \\
49(80.3)\end{array}$ & $\begin{array}{l}54(76.1) \\
17(23.9)\end{array}$ \\
\hline Professional level & $\begin{array}{l}\text { Pharmacist } \\
\text { Pharmacy } \\
\text { technician }\end{array}$ & $\begin{array}{l}\text { General doctor } \\
\text { Specialist }\end{array}$ & $\begin{array}{l}34(55.7) \\
27(44.3)\end{array}$ & $\begin{array}{l}22(31.0) \\
49(69.0)\end{array}$ \\
\hline $\begin{array}{l}\text { Years of working } \\
\text { experience }\end{array}$ & $\begin{array}{l}1-5 \\
6-10 \\
\geq 11\end{array}$ & & $\begin{array}{l}40(65.6) \\
11(18.0) \\
10(16.4)\end{array}$ & $\begin{array}{l}34(47.9) \\
12(16.9) \\
25(35.2)\end{array}$ \\
\hline $\begin{array}{l}\text { Monthly } \\
\text { income }(\mathrm{MNT})^{\mathrm{b}}\end{array}$ & $\begin{array}{l}90.000-200 \\
201.000-30 \\
\geq 301.000-4 \\
\geq 401.000\end{array}$ & 0 & $\begin{array}{l}9(15.0) \\
13(21.7) \\
23(38.3) \\
15(25.0)\end{array}$ & $\begin{array}{l}12(17.1) \\
28(40.0) \\
30(42.9)^{d}\end{array}$ \\
\hline
\end{tabular}

a Some responses were missing for each category

$437{ }^{\mathrm{b}}$ Mongolian National Tugrug, (MNT), currency, 100 USD was equivalent to 130000MNT at the time of study

$438{ }^{\mathrm{c}}$ The number represents respondents aged $\geq 31$ years old

$439{ }^{\mathrm{d}}$ The number represents respondents with a monthly income of $\geq 301.000 \mathrm{MNT}$ and higher 
440 Table 2 Questionnaire percentage frequencies of antibiotics dispensed with prescription or

441 provided OTC for treatment of CAP, orally and injection by pharmacists and pharmacy

442 technicians $(\mathrm{N}=61)$

\begin{tabular}{|c|c|c|c|c|c|c|}
\hline \multirow[t]{2}{*}{ 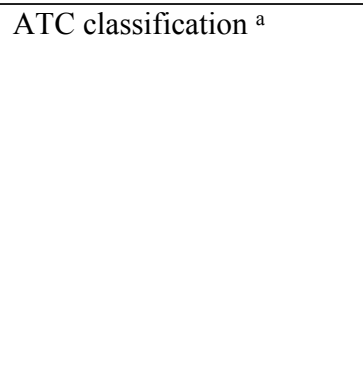 } & \multicolumn{3}{|c|}{ With prescription ${ }^{b}$} & \multicolumn{3}{|c|}{ Provided OTC ${ }^{b}$} \\
\hline & $\begin{array}{l}\text { Never/ } \\
\text { Rarely } \\
\text { n }(<10 \%)\end{array}$ & $\begin{array}{l}\text { Sometimes } \\
\mathrm{n}(11-40 \%)^{\mathrm{b}}\end{array}$ & $\begin{array}{l}\text { Often/ } \\
\text { Always } \\
\text { n }(>40 \%)\end{array}$ & $\begin{array}{l}\text { Never/ } \\
\text { Rarely } \\
\mathrm{n}(<10 \%)\end{array}$ & $\begin{array}{l}\text { Sometimes } \\
\mathrm{n}(11-40 \%)^{\mathrm{b}}\end{array}$ & $\begin{array}{l}\text { Often/ } \\
\text { Always } \\
\text { n }(>40 \%)\end{array}$ \\
\hline Aminopenicillins, oral & $77(31.6)$ & $70(28.7)$ & $97(39.8)$ & $79(32.4)$ & $73(29.9)$ & $92(37.7)$ \\
\hline Aminopenicillins, injection & $55(30.1)$ & $51(27.9)$ & $77(27.9)$ & $77(42.1)$ & $44(24.0)$ & $62(33.9)$ \\
\hline Quinolone, oral & $53(43.4)$ & $28(23.0)$ & $41(33.6)$ & $67(54.9)$ & $30(24.6)$ & $25(20.5)$ \\
\hline Quinolone, injection & $13(21.3)$ & $14(23.0)$ & $34(55.7)$ & $30(49.2)$ & $13(21.3)$ & $18(29.5)$ \\
\hline Cefalosporin, oral & $16(26.2)$ & $15(24.6)$ & $30(49.2)$ & $28(45.9)$ & $14(23.0)$ & $19(31.1)$ \\
\hline Cefalosporin, injection & $7(1.5)$ & $8(13.1)$ & $46(75.4)$ & $28(45.9)$ & $10(16.4)$ & $23(37.7)$ \\
\hline Macrolides, oral & $40(21.9)$ & $50(27.3)$ & $93(50.8)$ & $77(42.1)$ & $53(29.0)$ & $53(29.0)$ \\
\hline Macrolides, injection & $131(71.6)$ & $26(14.2)$ & $26(14.2)$ & $134(73.2)$ & $29(15.8)$ & $20(10.9)$ \\
\hline Tetracycline, oral & $103(84.4)$ & $16(13.1)$ & $3(2.5)$ & $91(74.6)$ & $19(15.6)$ & $12(9.8)$ \\
\hline Sulfonamid, oral & $18(29.5)$ & $19(31.1)$ & $24(39.3)$ & $17(27.9)$ & $18(29.5)$ & $26(42.6)$ \\
\hline
\end{tabular}

$444 \quad{ }^{\mathrm{b}}$ Respondents could choose more than option 
445 Table 3Frequencies of non-antibiotic medicines dispensed with prescription and provided 446 OTC for treatment of CAP, by pharmacists and pharmacy technicians $(\mathrm{N}=61)$

\begin{tabular}{|c|c|c|c|c|c|c|}
\hline \multirow[t]{2}{*}{ Other medicines $^{\mathrm{a}}$} & \multicolumn{3}{|c|}{ With prescription $^{b}$} & \multicolumn{3}{|c|}{ Provided OTC ${ }^{b}$} \\
\hline & $\begin{array}{l}\text { Never/ } \\
\text { Rarely } \\
\text { n }(<10 \%)\end{array}$ & $\begin{array}{l}\text { Sometimes } \\
\text { n }(11-40 \%)\end{array}$ & $\begin{array}{l}\text { Often/ } \\
\text { Always } \\
\text { n }(>40 \%)\end{array}$ & $\begin{array}{l}\text { Never/ } \\
\text { Rarely } \\
\mathrm{n}(<10 \%)\end{array}$ & $\begin{array}{l}\text { Sometimes } \\
\text { n }(11-40 \%)\end{array}$ & $\begin{array}{l}\text { Often/ } \\
\text { Always } \\
\text { n }(>40 \%)\end{array}$ \\
\hline Corticosteroid, oral & $31(50.8)$ & $19(31.1)$ & $11(18.0)$ & $35(59.3)$ & $16(27.1)$ & $8(13.6)$ \\
\hline Corticosteroid, injection & $19(31.1)$ & $24(39.3)$ & $18(29.5)$ & $28(48.3)$ & $24(41.4)$ & $6(10.3)$ \\
\hline Vitamin, oral & $31(26.1)$ & $42(35.3)$ & $46(38.7)$ & $28(23.7)$ & $30(25.4)$ & $60(50.8)$ \\
\hline Vitamin, injection & $88(49.4)$ & $56(31.5)$ & $34(19.1)$ & $97(55.1)$ & $42(23.9)$ & $37(21.0)$ \\
\hline Antihistamin, oral & $58(48.7)$ & $36(30.3)$ & $25(21.0)$ & $63(53.4)$ & $24(20.3)$ & $31(26.3)$ \\
\hline Antihistamin, injection & $37(62.7)$ & $15(25.4)$ & $7(11.9)$ & $41(70.7)$ & $11(19.0)$ & $6(10.3)$ \\
\hline Xanthin, ${ }^{\mathrm{c}}$ oral & $18(30.0)$ & $25(41.7)$ & $17(28.3)$ & $21(35.0)$ & $15(25.0)$ & $24(40.0)$ \\
\hline Xanthin, injection & $27(45.8)$ & $19(32.2)$ & $13(22.0)$ & $34(57.6)$ & $12(20.3)$ & $13(22.0)$ \\
\hline Pyrazolone, oral & $45(76.3)$ & $7(11.9)$ & $7(11.9)$ & $35(60.3)$ & $13(22.4)$ & $10(17.2)$ \\
\hline Pyrazolone, injection & $44(75.9)$ & $9(15.5)$ & $5(8.6)$ & $37(63.8)$ & $13(22.4)$ & $8(13.8)$ \\
\hline
\end{tabular}

447 aSome responses were missing for each category

$448 \quad$ b Respondents could choose more than option

$449{ }^{c}$ Xanthin is euphyllin 
450 Table 4 Percentage frequencies of characteristics that influence the practice of providing 451 medicines and prescribing for the treatment of CAP

\begin{tabular}{|c|c|c|c|c|c|c|}
\hline \multirow[t]{2}{*}{ Characteristic $^{a}$} & \multicolumn{3}{|c|}{$\begin{array}{l}\text { Pharmacists and pharmacy } \\
\text { technicians }(\mathrm{N}=61)\end{array}$} & \multicolumn{3}{|c|}{ Doctors $(\mathrm{N}=71)$} \\
\hline & $\begin{array}{l}\mathrm{D} / \mathrm{SD} \\
\mathrm{n}(\%)\end{array}$ & $\begin{array}{l}\mathrm{SA} / \mathrm{A} \\
\mathrm{n}(\%)\end{array}$ & $\begin{array}{c}\mathrm{NR} \\
\mathrm{n}(\%)\end{array}$ & $\begin{array}{l}\text { Never/ } \\
\text { Rarely } \\
\mathrm{n}(<10 \%)\end{array}$ & $\begin{array}{l}\text { Sometimes } \\
\mathrm{n}(11-40 \%)\end{array}$ & $\begin{array}{l}\text { Often/ } \\
\text { Always } \\
\mathrm{n}(>40 \%)\end{array}$ \\
\hline $\begin{array}{l}\text { The clinical effect of injections is more potent than oral } \\
\text { medicines' }\end{array}$ & $14(24.1)$ & $40(68.9)$ & $4(6.9)$ & $16(22.5)$ & $24(33.8)$ & $31(43.7)$ \\
\hline $\begin{array}{l}\text { The pharmaceutical quality of injections is better than } \\
\text { tablets/ capsules }\end{array}$ & $17(29.3)$ & $34(58.6)$ & $7(12.1)$ & $15(21.1)$ & $27(38.0)$ & $29(40.8)$ \\
\hline $\begin{array}{l}\text { Adverse events occur with oral drugs more than with } \\
\text { injections }\end{array}$ & $32(55.2)$ & $16(27.6)$ & $10(17.2)$ & $39(54.9)$ & $22(31.0)$ & $10(14.1)$ \\
\hline $\begin{array}{l}\text { The dosage form of injection is chosen for better } \\
\text { compliance of a patient }\end{array}$ & $9(15.8)$ & $39(68.4)$ & $9(15.8)$ & $34(47.9)$ & $6(36.6)$ & $11(15.5)$ \\
\hline The injection requires new syringes and needles & $8(13.8)$ & $48(82.8)$ & $2(3.4)$ & $2(2.8)$ & $7(9.9)$ & $62(87.3)$ \\
\hline $\begin{array}{l}\text { Training promotes more about treatment with an } \\
\text { injection than oral medicines }\end{array}$ & $38(65.5)$ & $12(20.7)$ & $8(13.8)$ & $52(73.2)$ & $15(21.1)$ & $4(5.6)$ \\
\hline $\begin{array}{l}\text { There is lot of advertisement about injections by drug } \\
\text { companies }\end{array}$ & $38(65.5)$ & $11(19.0)$ & $9(15.5)$ & $35(49.3)$ & $27(38.0)$ & $9(12.7)$ \\
\hline $\begin{array}{l}\text { Cost of treatment by oral medicines is more than the } \\
\text { treatment cost with injections (including cost of syringes } \\
\text { and needles) }\end{array}$ & $31(56.9)$ & $21(36.2)$ & $4(6.9)$ & $45(63.4)$ & $11(15.5)$ & $15(21.1)$ \\
\hline $\begin{array}{l}\text { If patients are prescribed an injection, they are required } \\
\text { to visit a pharmacy/hospital several times }\end{array}$ & $32(55.1)$ & $23(39.7)$ & $3(5.2)$ & $8(11.2)$ & $19(26.8)$ & $44(62.0)$ \\
\hline Patients prefer to use tablets rather than injection & $35(60.3)$ & $17(29.3)$ & $6(10.3)$ & $30(42.3)$ & $24(33.8)$ & $17(23.9)$ \\
\hline $\begin{array}{l}\text { When dispensing injections, patient's age, gender are } \\
\text { important }\end{array}$ & $10(17.2)$ & $44(75.9)$ & $4(6.9)$ & $8(11.3)$ & $16(22.5)$ & $47(66.2)$ \\
\hline Injection is chosen if patient had severe CAP & $10(17.2)$ & $46(79.3)$ & $2(3.4)$ & $16(22.5)$ & $21(29.6)$ & $34(47.9)$ \\
\hline
\end{tabular}


452 SA- Strongly agree, A-Agree, D- Disagree, SD- Strongly disagree, NR- No response

453 aSome responses were missing for each category 
Table $\mathbf{1}$ (on next page)

Table 1- Demographic characteristics of respondents

Demographic characteristics of respondents 
1 Table 1 Demographic characteristics of respondents

\begin{tabular}{|c|c|c|c|c|}
\hline \multirow[t]{2}{*}{ Variable $^{a}$} & \multirow{2}{*}{\multicolumn{2}{|c|}{ Category }} & $\begin{array}{l}\text { Pharmacists and pharmacy } \\
\text { technicians }(\mathrm{N}=61)\end{array}$ & $\begin{array}{l}\text { Doctors } \\
(\mathrm{N}=71)\end{array}$ \\
\hline & & & $\mathrm{n}(\%)$ & $\mathrm{n}(\%)$ \\
\hline Age (years) & $\begin{array}{l}20-30 \\
31-50 \\
\geq 51\end{array}$ & & $\begin{array}{l}22(36.1) \\
23(37.7) \\
16(26.2)\end{array}$ & $\begin{array}{l}26(36.6) \\
45(63.4)^{c}\end{array}$ \\
\hline Gender & \multicolumn{2}{|l|}{$\begin{array}{l}\text { Male } \\
\text { Female }\end{array}$} & $\begin{array}{l}14(23.0) \\
47(77.0)\end{array}$ & $\begin{array}{l}12(16.9) \\
59(83.1)\end{array}$ \\
\hline Practice setting & $\begin{array}{l}\text { Owner } \\
\text { Employee }\end{array}$ & $\begin{array}{l}\text { Public hospital } \\
\text { Private setting } \\
\text { (including FGPs } \\
\text { and others) }\end{array}$ & $\begin{array}{l}12(19.7) \\
49(80.3)\end{array}$ & $\begin{array}{l}54(76.1) \\
17(23.9)\end{array}$ \\
\hline Professional level & $\begin{array}{l}\text { Pharmacist } \\
\text { Pharmacy } \\
\text { technician }\end{array}$ & $\begin{array}{l}\text { General doctor } \\
\text { Specialist }\end{array}$ & $\begin{array}{l}34(55.7) \\
27(44.3)\end{array}$ & $\begin{array}{l}22(31.0) \\
49(69.0)\end{array}$ \\
\hline $\begin{array}{l}\text { Years of working } \\
\text { experience }\end{array}$ & $\begin{array}{l}1-5 \\
6-10 \\
\geq 11\end{array}$ & & $\begin{array}{l}40(65.6) \\
11(18.0) \\
10(16.4)\end{array}$ & $\begin{array}{l}34(47.9) \\
12(16.9) \\
25(35.2)\end{array}$ \\
\hline $\begin{array}{l}\text { Monthly } \\
\text { income }(\mathrm{MNT})^{\mathrm{b}}\end{array}$ & $\begin{array}{l}90.000-200 \\
201.000-30 \\
\geq 301.000-4 \\
\geq 401.000\end{array}$ & 0 & $\begin{array}{l}9(15.0) \\
13(21.7) \\
23(38.3) \\
15(25.0)\end{array}$ & $\begin{array}{l}12(17.1) \\
28(40.0) \\
30(42.9) \mathrm{d}\end{array}$ \\
\hline
\end{tabular}

2 a Some responses were missing for each category

3 b Mongolian National Tugrug, (MNT), currency, 100 USD was equivalent to 130000MNT at the time of study

$4 \quad{ }^{\mathrm{c}}$ The number represents respondents aged $\geq 31$ years old

$5 \mathrm{~d}$ The number represents respondents with a monthly income of $\geq 301.000 \mathrm{MNT}$ and higher 


\section{Table 2 (on next page)}

Table 2- Questionnaire percentage frequencies of antibiotics

Questionnaire percentage frequencies of antibiotics 
1 Table 1 Questionnaire percentage frequencies of antibiotics dispensed with prescription or

2 provided OTC for treatment of CAP, orally and injection by pharmacists and pharmacy

3 technicians $(\mathrm{N}=61)$

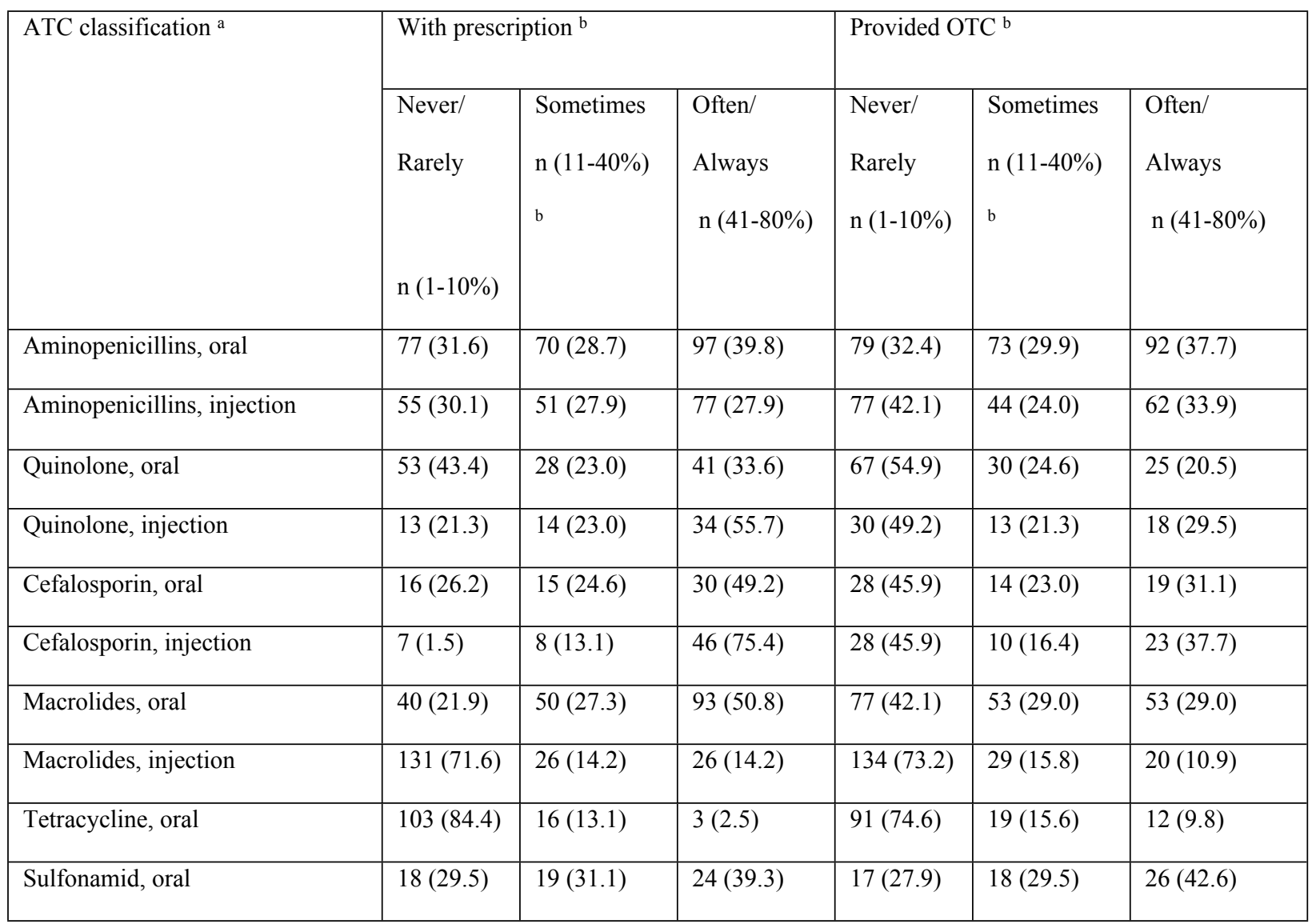

4 a Some responses were missing for each category

$5 \quad$ b Respondents could choose more than option 


\section{Table 3(on next page)}

Table 3- Frequencies of non-antibiotic medicines dispensed with prescription and provided OTC for treatment of CAP, by pharmacists and pharmacy technicians $(N=61)$

Frequencies of non-antibiotic medicines dispensed with prescription and provided OTC for treatment of CAP, by pharmacists and pharmacy technicians 
1 Table 1 Frequencies of non-antibiotic medicines dispensed with prescription and provided

2 OTC for treatment of CAP, by pharmacists and pharmacy technicians $(\mathrm{N}=61)$

\begin{tabular}{|c|c|c|c|c|c|c|}
\hline \multirow[t]{2}{*}{ Other medicines $^{\mathrm{a}}$} & \multicolumn{3}{|c|}{ With prescription $^{b}$} & \multicolumn{3}{|c|}{ Provided OTC ${ }^{b}$} \\
\hline & $\begin{array}{l}\text { Never/ } \\
\text { Rarely } \\
\text { n (1- } \\
10 \%)\end{array}$ & $\begin{array}{l}\text { Sometimes } \\
\text { n }(11-40 \%)\end{array}$ & $\begin{array}{l}\text { Often/ } \\
\text { Always } \\
\text { n (41-80\%) }\end{array}$ & $\begin{array}{l}\text { Never/ } \\
\text { Rarely } \\
\text { n }(1-10 \%)\end{array}$ & $\begin{array}{l}\text { Sometimes } \\
\mathrm{n}(11-40 \%)\end{array}$ & $\begin{array}{l}\text { Often/ } \\
\text { Always } \\
\text { n (41-80\%) }\end{array}$ \\
\hline Corticosteroid, oral & $31(50.8)$ & $19(31.1)$ & $11(18.0)$ & $35(59.3)$ & $16(27.1)$ & $8(13.6)$ \\
\hline Corticosteroid, injection & $19(31.1)$ & $24(39.3)$ & $18(29.5)$ & $28(48.3)$ & $24(41.4)$ & $6(10.3)$ \\
\hline Vitamin, oral & $31(26.1)$ & $42(35.3)$ & $46(38.7)$ & $28(23.7)$ & $30(25.4)$ & $60(50.8)$ \\
\hline Vitamin, injection & $88(49.4)$ & $56(31.5)$ & $34(19.1)$ & $97(55.1)$ & $42(23.9)$ & $37(21.0)$ \\
\hline Antihistamin, oral & $58(48.7)$ & $36(30.3)$ & $25(21.0)$ & $63(53.4)$ & $24(20.3)$ & $31(26.3)$ \\
\hline Antihistamin, injection & $37(62.7)$ & $15(25.4)$ & $7(11.9)$ & $41(70.7)$ & $11(19.0)$ & $6(10.3)$ \\
\hline Xanthin, ${ }^{\mathrm{c}}$ oral & $18(30.0)$ & $25(41.7)$ & $17(28.3)$ & $21(35.0)$ & $15(25.0)$ & $24(40.0)$ \\
\hline Xanthin, injection & $27(45.8)$ & $19(32.2)$ & $13(22.0)$ & $34(57.6)$ & $12(20.3)$ & $13(22.0)$ \\
\hline Pyrazolone, oral & $45(76.3)$ & $7(11.9)$ & $7(11.9)$ & $35(60.3)$ & $13(22.4)$ & $10(17.2)$ \\
\hline Pyrazolone, injection & $44(75.9)$ & $9(15.5)$ & $5(8.6)$ & $37(63.8)$ & $13(22.4)$ & $8(13.8)$ \\
\hline
\end{tabular}

3 a Some responses were missing for each category

$4 \quad{ }^{\mathrm{b}}$ Respondents could choose more than option

$5 \quad{ }^{c}$ Xanthin is euphyllin 


\section{Table 4(on next page)}

Percentage frequencies of characteristics that influence the practice of providing and prescribing for treatment of CAP

Table 4. Percentage frequencies of characteristics that influence the practice of providing medicines and prescribing for treatment of CAP 


\section{Table 1 Percentage frequencies of characteristics that influence the practice of providing 2 medicines and prescribing for the treatment of CAP}

\begin{tabular}{|c|c|c|c|c|c|c|}
\hline \multirow[t]{2}{*}{ Characteristic $^{\text {a }}$} & \multicolumn{3}{|c|}{$\begin{array}{l}\text { Pharmacists and pharmacy } \\
\text { technicians }(\mathrm{N}=61)\end{array}$} & \multicolumn{3}{|c|}{ Doctors $(\mathrm{N}=71)$} \\
\hline & $\begin{array}{l}\mathrm{D} / \mathrm{SD} \\
\mathrm{n}(\%)\end{array}$ & $\begin{array}{l}\mathrm{SA} / \mathrm{A} \\
\mathrm{n}(\%)\end{array}$ & $\begin{array}{l}\mathrm{NR} \\
\mathrm{n}(\%)\end{array}$ & $\begin{array}{l}\text { Never/ } \\
\text { Rarely } \\
\text { n }(1-10 \%)\end{array}$ & $\begin{array}{l}\text { Sometimes } \\
\mathrm{n}(11-40 \%)\end{array}$ & $\begin{array}{l}\text { Often/ } \\
\text { Always } \\
\text { n }(41-80 \%)\end{array}$ \\
\hline $\begin{array}{l}\text { The clinical effect of injections is more potent than oral } \\
\text { medicines' }\end{array}$ & $14(24.1)$ & $40(68.9)$ & $4(6.9)$ & $16(22.5)$ & $24(33.8)$ & $31(43.7)$ \\
\hline $\begin{array}{l}\text { The pharmaceutical quality of injections is better than } \\
\text { tablets/ capsules }\end{array}$ & $17(29.3)$ & $34(58.6)$ & $7(12.1)$ & $15(21.1)$ & $27(38.0)$ & $29(40.8)$ \\
\hline $\begin{array}{l}\text { Adverse events occur with oral drugs more than with } \\
\text { injections }\end{array}$ & $32(55.2)$ & $16(27.6)$ & $10(17.2)$ & $39(54.9)$ & $22(31.0)$ & $10(14.1)$ \\
\hline $\begin{array}{l}\text { The dosage form of injection is chosen for better } \\
\text { compliance of a patient }\end{array}$ & $9(15.8)$ & $39(68.4)$ & $9(15.8)$ & $34(47.9)$ & $6(36.6)$ & $11(15.5)$ \\
\hline The injection requires new syringes and needles & $8(13.8)$ & $48(82.8)$ & $2(3.4)$ & $2(2.8)$ & $7(9.9)$ & $62(87.3)$ \\
\hline $\begin{array}{l}\text { Training promotes more about treatment with an } \\
\text { injection than oral medicines }\end{array}$ & $38(65.5)$ & $12(20.7)$ & $8(13.8)$ & $52(73.2)$ & $15(21.1)$ & $4(5.6)$ \\
\hline $\begin{array}{l}\text { There is lot of advertisement about injections by drug } \\
\text { companies }\end{array}$ & $38(65.5)$ & $11(19.0)$ & $9(15.5)$ & $35(49.3)$ & $27(38.0)$ & $9(12.7)$ \\
\hline $\begin{array}{l}\text { Cost of treatment by oral medicines is more than the } \\
\text { treatment cost with injections (including cost of syringes } \\
\text { and needles) }\end{array}$ & $31(56.9)$ & $21(36.2)$ & $4(6.9)$ & $45(63.4)$ & $11(15.5)$ & $15(21.1)$ \\
\hline $\begin{array}{l}\text { If patients are prescribed an injection, they are required } \\
\text { to visit a pharmacy/hospital several times }\end{array}$ & $32(55.1)$ & $23(39.7)$ & $3(5.2)$ & $8(11.2)$ & $19(26.8)$ & $44(62.0)$ \\
\hline Patients prefer to use tablets rather than injection & $35(60.3)$ & $17(29.3)$ & $6(10.3)$ & $30(42.3)$ & $24(33.8)$ & $17(23.9)$ \\
\hline $\begin{array}{l}\text { When dispensing injections, patient's age, gender are } \\
\text { important }\end{array}$ & $10(17.2)$ & $44(75.9)$ & $4(6.9)$ & $8(11.3)$ & $16(22.5)$ & $47(66.2)$ \\
\hline Injection is chosen if patient had severe CAP & $10(17.2)$ & $46(79.3)$ & $2(3.4)$ & $16(22.5)$ & $21(29.6)$ & $34(47.9)$ \\
\hline
\end{tabular}


3 SA- Strongly agree, A-Agree, D- Disagree, SD- Strongly disagree, NR- No response

$4 \quad$ a Some responses were missing for each category 